\title{
Thigmomorphogenesis versus light in biomechanical growth strategies of saplings of two tropical rain forest tree species
}

\author{
Gaëlle JAOUEN $^{1 *}$, Meriem FouRNIER ${ }^{2}$, Tancrède ALMERAS ${ }^{1}$ \\ ${ }^{1}$ INRA, Unité Mixte de Recherche Ecologie des Forêts de Guyane (AgroParisTech, Cirad, CNRS, INRA, Université Antilles-Guyane) \\ Campus agronomique BP 70997379 Kourou Cedex, Guyane française \\ ${ }^{2}$ AgroParisTech, Unité Mixte de Recherche Laboratoire d'Étude des Ressources Forêt-Bois (AgroParisTech, INRA), 14 rue Girardet, \\ 54000 Nancy, France
}

(Received 31 March 2009; accepted 23 June 2009)

Keywords:

biomechanics /

thigmomorphogenesis /

height growth strategies /

tropical rain forest /

French Guiana
Mots-clés :

biomécanique /

thigmomorphogénèse /

stratégies de croissance en hauteur /

forêt tropicale humide /

Guyane française

\begin{abstract}
- In the dense tropical rainforest understorey, saplings exhibit different growth strategies aiming at reaching light levels better fitting their ecology. Investing mainly in height growth, at the expense of their width, a lot are close to mechanical instability. Tachigali melinonii, a long living heliophilic tree species, is frequently observed to be extremely slender and supported by neighbours. Such observations suggest an active growth control through the perception of mechanical environment.

- Mechanical environment or light availability, which one is the most influent on growth and slenderness (H/D)? To test this question, we recorded growth of control and staked saplings of two species with contrasting habits and ecology: T. melinonii, and Dicorynia guianensis, along a natural light gradient.

- Dicorynia, the more stable, responded more clearly to the staking treatment, showing slenderness increase when light is available, whereas for Tachigali, only light availability governed growth.

- For Tachigali, growth allocation is mainly governed by light availability and ontogeny, whereas Dicorynia is probably similar to the average tree strategy, using the thigmomorphogenetic physiological process to control its stability.
\end{abstract}

Résumé - Thigmomorphogénèse et effet de la lumière dans les stratégies biomécaniques de croissance de jeunes arbres de deux espèces de forêt tropicale humide.

- Dans le sous-bois dense tropical humide, les jeunes arbres développent différentes stratégies de croissance pour atteindre des niveaux de lumière mieux adaptés à leur écologie. En investissant massivement dans la croissance en hauteur aux dépens de leur épaisseur, beaucoup sont proches de la non-autoportance. Tachigali melinonii, héliophile à vie longue, est fréquemment observée extrêmement élancée, supportée par ses voisins. Ceci suggère un contrôle actif de la croissance par la perception de l'environnement mécanique.

- Qui, de l'environnement mécanique ou de la disponibilité de la lumière influence le plus la croissance et l'élancement? Nous avons observé la croissance de jeunes T. melinonii et Dicorynia guianensis (plus sciaphile), tuteurés ou non, le long d'un gradient naturel de lumière.

- Dicorynia, mécaniquement plus stable, est plus réactive aux tuteurs, investissant la biomasse produite dans la croissance en hauteur. La croissance en hauteur de Tachigali est uniquement gouvernée par la lumière disponible.

- Pour Tachigali, la disponibilité de la lumière et le stade ontogénique gouvernent principalement l'allocation de croissance. Dicorynia, comme probablement beaucoup d'espèces, utilise la thigmomorphogénèse pour contrôler sa stabilité.

*Corresponding author: gaelle.jaouen@ecofog.gf 


\section{INTRODUCTION}

In the tropical rain forest understorey, sapling growth is governed by the strong vertical gradient of light availability (Chazdon and Fetcher, 1984). According to the species shade tolerance, height growth strategy is thus a key parameter of sapling recruitment. Vertical foraging for light induces a risk of buckling, and the risk is greater for saplings than for older trees (Sterck and Bongers, 1998) and increases with the species shade-intolerance (van Gelder et al., 2006). In a previous work (Jaouen et al., 2007), we observed an unusual case: Tachigali melinonii (Harms), Caesalpiniaceae. This species has a very high buckling risk, which increases with neighbor competition index. Variation in buckling risk was mainly linked to modifications of slenderness (i.e. the ratio of height to diameter): the greater the disturbance, the greater the slenderness (Jaouen, 2007). Biomass is thus mainly allocated to stem length increase at the expense of increasing thickness. The saplings of this species are often not self-supporting anymore, leaning against bigger neighboring trees (pers. obs.).

Although unexpected for a tree species, this behavior seems very close to what is referred to as the "semi-self-supporting" habit of some lianas (Gallenmüller et al., 2004; Rowe and Speck, 1998). Semi-self-supporting climbers lean against their support, without specialized climbing structures, such as tendrils or hooks. Due to wide-angle branches, their attachment to the support is strong enough for very efficient climbing. After the support is located, their investment in the support function of the stem is assumed to decrease, as their stem stiffness tends to decrease. Thus, the saved biomass may be invested in stem length increase, which allows reaching higher light levels, such a behavior being consistent with the common shade-intolerance of lianas (Schnitzer and Bongers, 2002). This behavior is consistent with lianas affinity for disturbed environments (Schnitzer and Carson, 2001), where fallen trees provide supports and induce gaps where regeneration, and thus stem density, are high (Brokaw, 1985). T. melinonii, which is an heliophilic long living species often found in disturbed habitats (Favrichon, 1995), follows such an opportunistic growth strategy. Then, its higher slenderness in disturbed habitats could be linked to changes in growth allocation dueer to changes in its mechanical micro-environment after finding a support. As well, the support prevents swaying and bending induced by winds or self-weight, to which growth is very sensitive (Moulia et al., 2006). The ability to modify its growth allocation (Biddington, 1986), and thus its slenderness (Jaffe et al., 2002), according to the perception of the mechanical environment, is thigmomorphogenesis (Boyer, 1967), i.e. the reaction of plant to touch and other mechanical stimuli. This is then the thigmomorphogenetic hypothesis.

An alternative, physiological, hypothesis may explain the plasticity in T. melinonii's slenderness. A well-known consequence of competition for light between trees is a modification of absolute growth and of its distribution between length and thickness (Coomes and Grubb, 1998; Larson, 1963). High competition for light induces more slender stems (King, 1990). Thus, the extreme slenderness of T. melinonii stems may be solely due to competition for light, which may decrease its mechanical stability. Since mechanical failure would increase mortality rates, saplings that find supports may be more likely to survive. According to this physiological hypothesis, no thigmomorphogenetic process is involved, only chance and selective mortality.

The aim of this work was to test the relevance of the two hypotheses. From experiments in controlled environment reported in the literature, there is no doubt that both thigmo(Jaffe et al., 2002) and photomorphogenetic (Messier and Nikinmaa, 2000; Poorter, 2001) effects on tree growth exist with interactive effects as thigmo-sensitivity increases with light unavailability (Holbrook and Putz, 1989; Pappas and Mitchell, 1982; Rowe and Speck, 2005), but very few data are available in natural conditions. Naturally recruited T. melinonii saplings were sampled along a gradient of light availability in the understorey. Half of them were staked. Their growth and growth allocation were followed. Thigmomorphogenesis implies a perception of a mechanical environment that is to be quantified (as light microclimate) (Coutand et al., 1997). Here, the staking treatment is supposed to simulate the effect of an external support as it prevents the plant from any sway and bending. Support will be given to the thigmomorphogenetic hypothesis if the staking significantly modifies growth and slenderness. The physiological hypothesis is that the only predictor of growth and slenderness is the light availability, regardless of the presence of a support. To flesh out conclusions about T. melinonii strategy, a second species, Dicorynia guianensis (Amshoff), Caesalpiniaceae, known to be mechanically more stable (Jaouen, 2007), was compared. This species is well known for its moderate shade-tolerance (Favrichon, 1994) and ability to germinate and grow in a wide range of environments (Van der Meer et al., 1998). It has intermediate photosynthetic characteristics (Rijkers et al., 2000), and growth rates (Favrichon, 1994; Flores et al., 2006) which depend strongly on light availability (Baraloto et al., 2005; Gourlet-Fleury, 2002). Its buckling risk, slenderness and wood stiffness are all of average values (Jaouen, 2007) and it has never been observed not-self supporting. By comparing T. melinonii with D. guianensis, we aim at choosing which of both hypotheses is the more relevant a higher thigmomorphogenetic sensitivity or a higher sensitivity to competition for light. Such results will be used to establish further hypotheses concerning thigmomorphogenesis implication in saplings growth strategies.

\section{MATERIALS AND METHODS}

\subsection{Study sites and sampling method}

This experiment was performed at the Paracou Experimental Research Station ( $\left.5^{\circ} 18^{\prime} \mathrm{N}, 52^{\circ} 23^{\prime} \mathrm{W}\right)$ (Gourlet-Fleury et al., 2004), a tropical rain forest situated in the coastal part of French Guiana, South America, between September 2004 and June 2006.

We sampled individuals along gradients of size and light availability. Height $(H)$ and diameter $(D) 20 \mathrm{~cm}$ above ground were measured, with a tape measure, on saplings of both species. Saplings ranged from 0.5 to $4 \mathrm{~m}$ in height. Dawkins index, a determination 


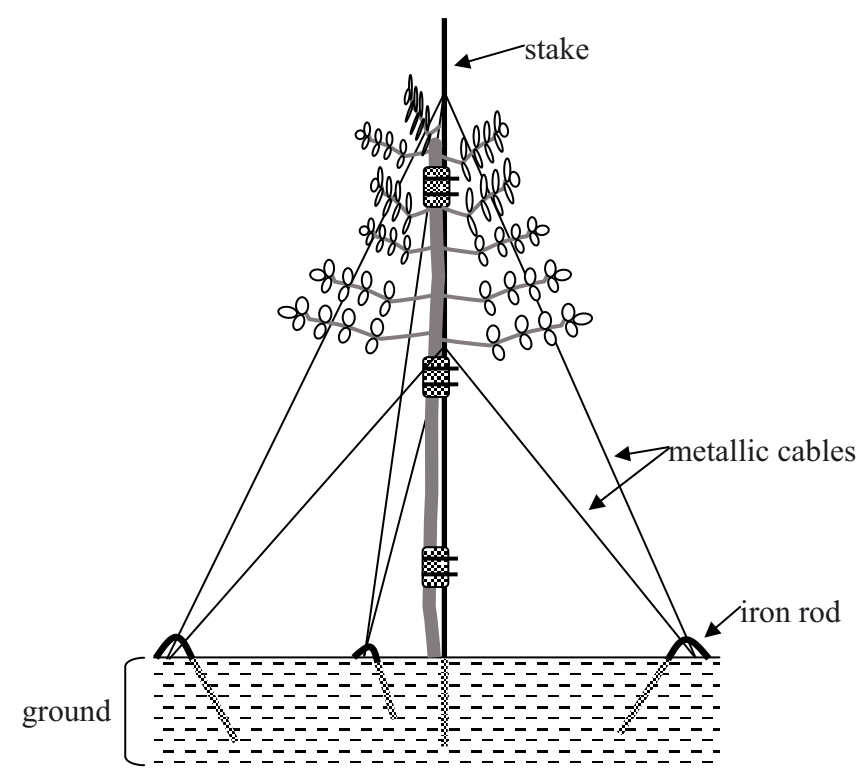

Figure 1. Experimental set-up for staking saplings. See the text for all details.

of light availability based on canopy openness (Dawkins, 1958), was estimated for each sapling by twin independent operators. The mean of the two estimates was used to attribute a value comprised between 1 and 5 (from the closest to the most open canopy) to each sapling. Saplings were randomly assigned to one of two treatments: staked or un-staked. The natural forest heterogeneity made the statistical analysis of paired plants initially planned impossible, as it was scarcely possible to find two plants of same size in similar light conditions. At the end of the experiment, plants or staking devices that have been destroyed (e.g. by animals or falling trees) were excluded, and results were available for 62 saplings for D. guianensis and 34 for T. melinonii. Initial sapling size (height and diameter) was uncorrelated with light index, whatever species and treatment $(p>0.05)$. There were no significant differences $(p>0.01)$ between sub-samples concerning height, diameter, slenderness (H/D) and Dawkins index, for each species.

\subsection{Staking and measurements}

The stakes were made of $30 \mathrm{~mm}$-diameter hollow aluminium tubes (Fig. 1). Each tube was embedded $50 \mathrm{~cm}$ deep in the ground and at least $70 \mathrm{~cm}$ higher than the saplings it supported. To prevent any movements of the stakes, the tubes were guyed in three directions at one level (or two levels for the tallest individuals). The guy wires were fixed to the ground by curved iron rods. Sapling stems were fixed to the stake by plastic sheathes maintained by clamping rings. The sheathes were about $10 \mathrm{~cm}$ long and distributed all along the stem from the base to the most apical part in order to restrain the whole trunk. The branches were kept free. This arrangement did not modify the light environment. To minimize within-sapling variation in response to staking, we used multiple attachment points and regularly checked that the stems were well fixed but not hurt by the device (Mattheck, 1990). We recorded sapling height and diameter $20 \mathrm{~cm}$ above ground initially and approximately every $100 \mathrm{~d}$ thereafter. The slenderness was calculated as $H / D\left(\mathrm{~cm} . \mathrm{cm}^{-1}\right)$. The saplings of
T. melinonii and D. guianensis were followed for $645 \mathrm{~d}$ and $309 \mathrm{~d}$, respectively (the experiment for $D$. guianensis was installed one year later).

\subsection{Data analysis}

The growth values $(\Delta H$ and $\Delta D)$ and slenderness variations $(\Delta(H / D))$ were calculated for the same unit of time (a year) in order to allow comparisons between species. Mean values of growth and slenderness were compared between samples using the confidence limits $(C L)(95 \%)$ or analyses of variance. Then, the effects of light and treatment (control/staked) on growth, slenderness and slenderness variations were analyzed through linear relationships. The differences between species and treatments were tested with an analysis of covariance. This analysis provided an $F$-test to check if separate linear models (one for each species or each treatment), with the light index as predictive variable, better explained growth or slenderness variations variability than a single (general) common linear model. All the analyses were performed using the software Statistica 7.1 (StatSoft France (2006) www.statsoft.fr) and particularly the tool "slopes homogeneity model".

\section{RESULTS}

No significant relationships $(p>0.05)$ were found between growth $(\Delta H$ and $\Delta D)$ and initial size $(H$ and $D$, resp.) for all the sub-samples, apart from $D$. guianensis staked saplings ( $R=0.43, p=0.01$ for both $H$ and $D$ ). Mean height and diameter growth were small but significantly different from 0 $(p<0.05)$ and very similar for the two species (Tab. I). The mean initial slenderness of $T$. melinonii saplings was significantly greater than for $D$. guianensis: $144 \pm 10 C L \mathrm{~cm} . \mathrm{cm}^{-1}$ versus $99 \pm 7 C L \mathrm{~cm} . \mathrm{cm}^{-1}(p<0.05)$.

Significant positive relationships $(p<0.05)$ were found between growth and light index for both species. Light index explained $53 \%$ of the variability of the height growth of T. melinonii but only $21 \%$ for Dicorynia guianensis (resp. $33 \%$ and $7 \%$ for the diameter growth). No significant differences of growth were found between control and staked saplings for both species (Tab. I).

There were no statistical differences between species and between treatments, whatever the species, for the slenderness variations (Tab. II). Slenderness variation was significantly related to light index for T. melinonii whole sample but not for D. guianensis whole samples (Tab. II). The linear models linking slenderness variations to the light index were statistically $(p<0.05)$ different between species. For T. melinonii, both control and staked saplings slenderness variations were positively linked with light index (Tab. II, Fig. 2A) and the use of separate linear models was not necessary $(p<0.05)$. For $D$. guianensis, control and staked saplings slenderness variations were significantly linked with light index (Tab. II, Fig. 2B), but not in the same way: negatively for control saplings and positively for staked saplings. Separate linear models, one for each treatment, were statistically necessary for D. guianensis. 

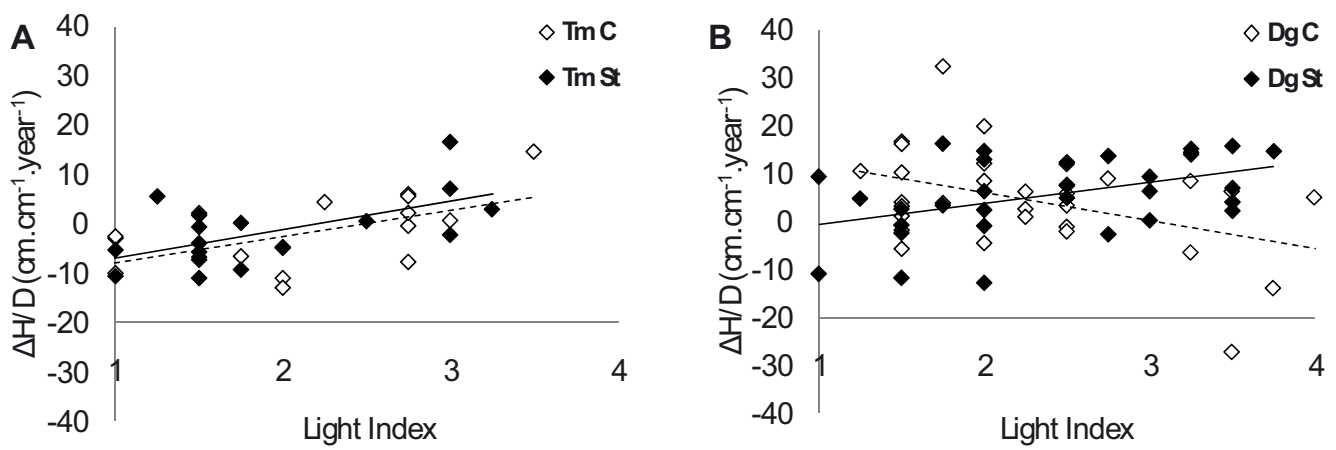

Figure 2. Slenderness variations according to the light index for T. melinonii (A) and D. guianensis (B). The linear regressions curves (see Tab. II) are represented by dotted lines for control saplings and continuous lines for staked saplings.

Table I. Height and diameter annual growths (mean \pm confidence limit $95 \%$ ). The first column contains the sub sample names: $D g$ for Dicorynia guianensis and Tm for Tachigali melinonii; $C$ for control, St for staked and All for control and staked saplings all together. The second column gives the samples sizes $(N)$.

\begin{tabular}{llcc}
\hline & $N$ & $\Delta H\left(\mathrm{~cm}^{\text {year }}{ }^{-1}\right) \pm \mathrm{CL}$ & $\Delta D\left(\mathrm{~cm}^{\text {year }}{ }^{-1}\right) \pm \mathrm{CL}$ \\
\hline Tm C & 16 & $12.40 \pm 9.20$ & $0.11 \pm 0.05$ \\
Tm St & 18 & $8.88 \pm 6.99$ & $0.07 \pm 0.03$ \\
Tm All & 34 & $10.54 \pm 5.41$ & $0.09 \pm 0.03$ \\
Dg C & 30 & $12.11 \pm 5.14$ & $0.04 \pm 0.06$ \\
Dg St & 32 & $14.93 \pm 5.60$ & $0.06 \pm 0.03$ \\
Dg All & 62 & $13.56 \pm 3.72$ & $0.05 \pm 0.03$ \\
\hline
\end{tabular}

Table II. Slenderness variations $\left(\mathrm{cm} \cdot \mathrm{cm}^{-1} \cdot\right.$ year $^{-1} \pm$ CL 95\%) exhibited by each sub sample and the whole sample for each species (for names details see Tab. I) and characteristics (slope, determination coefficient and $p$-value) of the relationships between slenderness variations and the light index.

\begin{tabular}{lcccc}
\hline & $\Delta H / D\left(\mathrm{~cm}^{-1} \mathrm{~cm}^{-1}\right.$ year $\left.^{-1}\right) \pm \mathrm{CL}$ & Slope & $R^{2}$ & $p$ \\
\hline Tm C & $-1.56 \pm 3.91$ & 5.37 & 0.32 & $p<0.05$ \\
Tm St & $-1.83 \pm 3.48$ & 5.81 & 0.37 & $p<0.01$ \\
Tm All & $-1.70 \pm 2.46$ & 5.42 & 0.33 & $p<0.01$ \\
Dg C & $4.57 \pm 4.01$ & -5.82 & 0.17 & $p<0.05$ \\
Dg St & $5.65 \pm 2.90$ & 4.45 & 0.20 & $p<0.01$ \\
Dg All & $5.13 \pm 2.38$ & -0.18 & 0.00 & $p=0.91$ \\
\hline
\end{tabular}

\section{DISCUSSION}

With this experiment, we showed an interspecific difference of sensitivity to the mechanical environment. The general slenderness increase with light index in Tachigali melinonii was quite unexpected as high slenderness is usually associated with poor light availability. In our sample, at the sapling stage, light certainly limited growth. Therefore, at this stage, whatever the light conditions, T. melinonii invests strongly in height growth rather than in diameter growth with the aim of reaching higher light levels. Predominance of light on thigmomorphogenesis is consistent with the results of Holbrook and Putz (1989) who have shown, on young Liquidambar styraciflua, that slenderness was governed by light foraging more than by the presence of a stake. This behavior should be typical of heliophilic species where the investment in height growth is a priority. Following the typology of growth strategy de- veloped by Oldeman et al. (1991) between "gamblers" and "strugglers", we can qualify the heliophilic unstable Tachigali melinonii as a "blind" gambler, with a growth allocation mainly governed by light availability and ontogeny. Lastly, the basic trait that allows T. melinonii to behave as it, is probably its observed ability to tangle its thin and flexible branches and composite leaves in neighbor ones. It makes T. melinonii a branch angle climber according to the typology of climbers of Rowe and Speck (2006) (and the opposite of a crown-shy species).

Contrastingly, slenderness of unstaked D. guianensis saplings significantly decreased in higher light conditions. This species is less in urgent need of reaching higher light levels and the better light conditions allow a stronger investment in radial growth. But the treatment modified the way light influences growth and slenderness: for staked plants, 
slenderness did not decrease anymore and the produced biomass was preferentially invested in height growth. Therefore, Dicorynia guianensis seems more sensitive to its mechanical environment, and may be such an ability to control actively its self-supporting habit is a strong character of tree growth strategy.

We expected the lianoïd species to be the most sensitive species as a strong ability to change its growth allocation when supported is the basic trait that allows changing habit from self supporting to not self supporting one. However, the lianoïd species had the lowest sensitivity. As suggested by Moulia et al. (2006), thigmo- and photomorphogenetic performance traits should be submitted to a high selective pressure: a tree not able to adapt its growth allocation to its mechanical and light microclimates should fall down and/or die, because of a lack of light or a too high biomass cost to maintain its stability.

The originality of this experiment (staking in natural conditions) may explain the poorness of some of our statistical results. A lot of factors are uncontrolled and highly variable. The staking implies that the branches remain free so that their movements (wind, animals, other plants) may induce mechanical constraints which decrease the relative effects of the stake on the whole plant's mechanical stress. Actually, wide branch climbers as T. melinonii, supposed to take benefit from the thigmomorphogenetic process to increase their investment in height growth, are attached by branches, and not staked on a mast (Rowe et al., 2006).

Further works should concern more accurate studies between species differences, among a wide range of species or genotypes, and in more accurately controlled light conditions.

Acknowledgements: This experiment was financially supported by the program "Projets innovants" of the French institute INRA, then by the ANR project "Woodiversity". We thank the persons who help us during the preparation of this experiment, the installation and the measurements: Pascal Imbert, Adrien Bruère, Aline Etlicher, Karen Christensen-Dalsgaard, Rufus Charles, Sabrina Coste, Patrick Heuret and Lisa Keinig. We also thank the AgroParisTech students who helped us to sample the saplings during the training course "FTH" in 2004.

\section{REFERENCES}

Baraloto C., Goldberg D.E., and Bonal D., 2005. Performance trade-offs among tropical tree seedlings in contrasting microhabitats. Ecology 86: $2461-2472$.

Biddington N.L., 1986. The effects of mechanically-induced stress in plants - a review. Plant Growth Regul. 4: 103-123.

Boyer N., 1967. Modifications de la croissance de la tige de Bryone (Bryonia dioica) à la suite d'irritations tactiles. C. R. Acad. Sci. 264: 2114-2117.

Brokaw N.V.L., 1985. Gap-phase regeneration in a tropical forest. Ecology 66: 682-687.

Chazdon R.L. and Fetcher N., 1984. Light environments of tropical forests. In: Medina E., Mooney H.A., and Vazquez-Yanes C. (Eds.), Physiological ecology of plants of the wet tropics, Junk, The Hague, Netherlands, pp. 27-36.

Coomes D.A. and Grubb P.J., 1998. Responses of juvenile trees to aboveand beloweground competition in nutrient-starved amazonian rain forest. Ecology 79: 768-782.
Coutand C., Moulia B., Frizot N., Mauget J.C., and Julien J.-L., 1997. An experimental method for quantitative characterization of plant thigmomorphogenesis. In: Jeronimidis G. and Vincent J.F.V. (Eds.), Plant biomechanics, Centre for Biomimetics, Reading.

Dawkins H.C., 1958. The management of natural tropical highforests with special reference to Uganda. Imperial Forestry Institute, University of Oxford, $155 \mathrm{p}$.

Favrichon V., 1994. Classification des espèces arborées en groupes fonctionnels en vue de la réalisation d'un modèle de dynamique de peuplement en forêt guyanaise. Terre Vie-Rev. Ecol. A 49: 379-403.

Favrichon V., 1995. Modèle matriciel déterministe en temps discret: application à l'étude de la dynamique d'un peuplement forestier tropical humide (Guyane française). Thèse, Université Claude Bernard Lyon 1, France, 252 p.

Flores O., Gourlet-Fleury S., and Picard N., 2006. Local disturbance, forest structure and dispersal effects on sapling distribution of lightdemanding and shade-tolerant species in a French Guianian forest. Acta Oecol. 29: 141-154.

Gallenmüller F., Rowe N.P., and Speck T., 2004. Development and growth form of the neotropical liana Croton nuntians: the effect of light and mode of attachment on the biomechanics of the stem. J. Plant Growth Regul. 23: 83-97.

Gourlet-Fleury S., 2002. Régénération de l'Angélique (Dicorynia guianensis Amshoff., Caesalpiniaceae) en Guyane française. Rapport final projet Ecofor : Étude qualitative et quantitative du déterminisme de la reproduction, de l'installation et du développement des nouveaux individus dans le peuplement. Cirad, $60 \mathrm{p}$.

Gourlet-Fleury S., Guehl J.-M., and Laroussinie O., 2004. Ecology and management of a neotropical rainforest. Lessons drawn from Paracou, a long-term experimental research site in French Guiana, Paris, France, 350 p.

Holbrook M.N. and Putz F.E., 1989. Influence of neighbors on tree form: effects of lateral shade and prevention of sway on the allometry of Liquidambar styraciflua (sweet gum). Am. J. Bot. 76: 1740-1749.

Jaffe M.J., Leopold A.C., and Staples R.C., 2002. Thigmo responses in plants and fungi. Am. J. Bot. 89: 375-382.

Jaouen G., 2007. Étude des stratégies biomécaniques de croissance des jeunes arbres en peuplement hétérogène tropical humide. Biologie végétale et forestière, Thèse, Université Henri Poincaré, Nancy I, France, $217 \mathrm{p}$.

Jaouen G., Alméras T., Coutand C., and Fournier M., 2007. How to determine sapling buckling risk with only a few measurements. Am. J. Bot. 94: 1583-1593.

King D.A., 1990. Allometry of saplings and understory trees of a panamanian forest. Funct. Ecol. 4: 27-32.

Larson P.R., 1963. Stem form development of forest trees. For. Sci. Monogr. 5: 1-42.

Mattheck C., 1990. Engineering Components grow like trees. Materialwiss, Werkst. 21: 143-168.

Messier C. and Nikinmaa E., 2000. Effects of light availability and sapling size on the growth, biomass allocation, and crown morphology of understory sugar maple, yellow birch, and beech. Ecoscience 7: $345-356$.

Moulia B., Coutand C., and Lenne C., 2006. Posture control and skeletal mechanical acclimation in terrestrial plants: implications for mechanical modeling of plant architecture. Am. J. Bot. 93: 1477-1489.

Oldeman R.A.A. and Van Dijk J., 1991. Diagnosis of the temperament of tropical rain forest trees. In: Gomez-Pompa A., Whitmore T.C., and Hadley M. (Eds.), Rain forest regeneration and management, UNESCO and The Parthenon publishing group, Paris, France, pp. 21-65.

Pappas T. and Mitchell C.A., 1982. Mechanical stress regulation of growth and photosynthetic productivity of Glycine max/L./Merr. cv Wells II under different environmental regimes (soybean plant 
growth retardation by shaking and rubbing). Physiologist 25: S135-S136.

Poorter L., 2001. Light-dependent changes in biomass allocation and their importance for growth of rain forest tree species. Funct. Ecol. 15: $113-123$.

Rijkers T., Pons T.L., and Bongers F., 2000. The effect of tree height and light availability on photosynthetic leaf traits of four neotropical species differing in shade tolerance. Funct. Ecol. 14: 77-86.

Rowe N.P. and Speck T., 1998. Biomechanics of plant growth forms: the trouble with fossil plants. Rev. Palaeobot. Palynol. 102: 43-62.

Rowe N.P. and Speck T., 2005. Plant growth forms: an ecological and evolutionary perspective. New Phytol. 166: 61-72.

Rowe N.P., Isnard S., Gallenmüller F., and Speck T., 2006. Diversity of mechanical architectures in climbing plants: an ecological perspective. In: Herrel A., Speck T., and Rowe N.P. (Eds.), Ecology and biomechanics. A mechanical approach to the ecology of animals and plants, Taylor and Francis, CRC Press.

Schnitzer S.A. and Carson W.P., 2001. Treefall gaps and the maintenance of species diversity in a tropical forest. Ecology 82: 913-919.

Schnitzer S.A. and Bongers F., 2002. The ecology of lianas and their role in forests. Trends Ecol. Evol. 17: 223-230.

Sterck F.J. and Bongers F., 1998. Ontogenetic changes in size, allometry, and mechanical design of tropical rain forest trees. Am. J. Bot. 85: 266-272.

Van der Meer P.J., Sterck F.J., and Bongers F., 1998. Tree seedling performance in canopy gaps in a tropical rain forest at Nouragues, French Guiana. J. Trop. Ecol. 14: 119-137.

van Gelder H.A., Poorter L., and Sterck F.J., 2006. Wood mechanics, allometry, and life-history variation in a tropical rain forest tree community. New Phytol. 171: 367-378. 